\title{
Positive effects of a dominant invader on introduced and native mudflat species
}

\author{
Marjorie J. Wonham ${ }^{1,3, *}$, Mary O'Connor ${ }^{2,4}$, Christopher D. G. Harley ${ }^{1,5}$ \\ ${ }^{1}$ Department of Zoology, University of Washington, PO Box 351800, Seattle, Washington 98195-1800, USA \\ ${ }^{2}$ Brown University, PO Box 3306, Providence, Rhode Island 02912, USA 02912 \\ ${ }^{3}$ Present address: Department of Biological Sciences and Department of Mathematical and Statistical Sciences, \\ University of Alberta, CAB 632, Edmonton, Alberta T6G 2G1, Canada \\ ${ }^{4}$ Present address: University of North Carolina at Chapel Hill, 12-7 Venable Hall, CB\# 3300, Chapel Hill, \\ North Carolina 27599-3300, USA \\ ${ }^{5}$ Present address: Bodega Marine Laboratory, PO Box 247, Bodega Bay, California 94923-0247, USA
}

\begin{abstract}
Many introduced species have negative impacts on native species, but some develop positive interactions with both native species and other invaders. Facilitation between invaders may lead to an overall acceleration in invasion success and impacts. Mechanisms of facilitation include habitat alteration, or ecosystem engineering, and trophic interactions. In marine systems, only a handful of positive effects have been reported for invading species. In an unusual NE Pacific marine assemblage dominated by 5 conspicuous invaders and 2 native species, we identified positive effects of the most abundant invader, the Asian hornsnail Batillaria attramentaria, on all other species. $B$. attramentaria reached densities $>1400 \mathrm{~m}^{-2}$, providing an average of $600 \mathrm{~cm}$ of hard substrate per $\mathrm{m}^{2}$ on this mudflat. Its shells were used as habitat almost exclusively by the introduced Atlantic slipper shell Crepidula convexa, the introduced Asian anemone Diadumene lineata, and 2 native hermit crabs Pagurus hirsutiusculus and $P$. granosimanus. In addition, manipulative experiments showed that the abundance of the mudsnail Nassarius fraterculus and percentage cover of the eelgrass Zostera japonica, both introduced from the NW Pacific, increased significantly in the presence of B. attramentaria. The most likely mechanisms for these facilitations are indirect grazing effects and bioturbation, respectively. Since the precise arrival dates of all these invaders are unknown, the role of $B$. attramentaria's positive interactions in their initial invasion success is unknown. Nevertheless, by providing habitat for 2 non-native epibionts and 2 native species, and by facilitating 2 other invaders, the non-native $B$. attramentaria enhances the level of invasion by all 6 species.
\end{abstract}

KEY WORDS: Biological invasion impacts - Positive interactions · Facilitation - Ecosystem engineering $\cdot$ Pacific Northwest

\section{INTRODUCTION}

The impacts of introduced species are generally reported in terms of negative effects on native species (e.g. Parker et al. 1999, Grosholz 2002). In some cases, however, an invader may have positive effects on native species (e.g. Crooks 2002) or other invaders (Simberloff \& Von Holle 1999, Richardson et al. 2000, Ricciardi 2001). Positive interactions, namely mutualisms $(+/+)$ and 1 side of both commensal $(+/ 0)$ and exploitative (+/-) relationships, have thus far only rarely been reported between marine invaders
(Crooks 2002, Levin et al. 2002, Wonham 2003). As the prevalence and ecological importance of positive interactions are increasingly recognized in marine systems (Peterson \& Heck 2001, Stachowicz 2001, Bruno et al. 2003, Mouritsen 2004), we anticipate an increase in reports of facilitative interactions with invaders as well. Based on observations in other systems (Simberloff \& VonHolle 1999, Richardson et al. 2000) these facilitations will likely include pairs of introduced species that were previously associated in their native ranges, and non-co-evolved species in their new regions of sympatry. 
Mechanisms of facilitation between invaders and resident (introduced or native) species in terrestrial communities are primarily plant pollination and dispersal by animals, mycorrhizal relationships, and habitat alteration by both animals and plants (D'Antonio \& Vitousek 1992, Simberloff \& VonHolle 1999, Davis et al. 2000, Richardson et al. 2000). In aquatic systems, where the first of these relationships are less relevant, habitat alteration or ecosystem engineering (Crooks 2002, Lambert \& Lambert 2003, Castilla et al. 2004) and trophic interactions (e.g. Alpine \& Cloern 1992, Kitchell et al. 1997, Ricciardi 2003) may be the most important mechanisms of invader impacts, including facilitation. The same likely holds for marine communities.

In the present study, we identify an unusual marine assemblage consisting almost entirely of 6 macroinvertebrates and 1 vascular plant, of which all but 2 are introduced species. The introduced Asian hornsnail Batillaria attramentaria (Crosse 1862) (previously referred to as B. zonalis and B. cumingi in Pacific coast literature) is by far the most abundant animal in this system. As a diatom grazer and bioturbator (Whitlatch \& Obrebski 1980, Byers 2000, Kamimura \& Tsuchiya 2004), we expected that it could influence sediment chlorophyll levels and the abundance of other grazers through grazing; the abundance of shell epibionts and occupants through habitat provision; sediment particle size through bioturbation; and eelgrass percentage cover through bioturbation and pseudofecal deposition. We used field surveys and experimental manipulations to evaluate these potential relationships.

\section{MATERIALS AND METHODS}

Study system. We conducted our study in Padilla Bay, a shallow sheltered $\sim 14 \mathrm{~km}$ long bay in northern Puget Trough, Washington, USA $\left(48^{\circ} 40^{\prime} \mathrm{N}, 122^{\circ}\right.$ $50^{\prime} \mathrm{W}$ ). (Site maps available in $\mathrm{O}^{\prime}$ Connor et al. 2002 and Wonham \& Carlton 2005.) In the upper-mid intertidal mudflats, the Asian hornsnail Batillaria attramentaria (hereafter Batillaria) and Asian eelgrass Zostera japonica Aschers. \& Graebn. are highly abundant, and the Asian mudsnail Nassarius fraterculus (Dunker 1860) (hereafter Nassarius) is present but less common. Batillaria shell surfaces are colonized primarily by the introduced Atlantic slipper shell Crepidula convexa Say 1822 (hereafter Crepidula) and the introduced Asian anemone Diadumene lineata (Verrill 1869) (hereafter Diadumene). Empty shells are used by native hermit crabs Pagurus hirsutiusculus and P. granosimanus, which were counted together for the purposes of this study (hereafter, Pagurus spp.). Batillaria, Nassarius, Crepidula, and Z. japonica are reported from Padilla Bay since 1970 (Penttila 1971, D. Penttila,
Washington Department of Fish and Wildlife, pers. comm. to M. J. Wonham). All 5 non-native species were introduced with commercial oyster shipments in the late 1800s to early 1900s; Diadumene may also have been transported on ship hulls (Carlton 1979, 1987, 1992, Gollasch \& Riemann-Zürneck 1996, Byers 2000, Wasson et al. 2001). No other mudflat snails are reported from Padilla Bay or similar habitats in the region (Sylvester \& Clogston 1958, Jeffrey 1976, Carlton 1979), or were seen during this study (authors' pers. obs.). The native snails Lacuna vincta, Littorina spp., and Nucella spp. are found in nearby habitats, but their shells are rarely found on the mudflat. For further details of site and methods see O'Connor et al. (2002).

Spatial distribution surveys. In a series of surveys, we estimated Batillaria abundance and size, the abundance of empty Batillaria shells, Nassarius, and Pagurus spp., the percentage cover of Zostera japonica, and the abundance of Batillaria shell epibionts. Since the bay is wide and shallow, we measured distance from shore rather than intertidal height. A distance of $100 \mathrm{~m}$, where Batillaria tends to be most abundant (authors' pers. obs.), corresponds to approximately $45 \mathrm{~cm}$ above Mean Lower Low Water.

We estimated Batillaria, Nassarius, and Pagurus spp. abundances at $100 \mathrm{~m}$ from shore in 5 surveys at 12 sites 0.5 to $1 \mathrm{~km}$ apart, in September and November 1999 and January, March, and November 2000 (Survey 1). To quantify the broader distribution of Batillaria and Zostera japonica, we estimated Batillaria abundance and size and $Z$. japonica percentage cover at 50,100, and $150 \mathrm{~m}$ from shore at the same sites on 1 occasion in August 1999 (Survey 2). At a local scale, we used intensive surveys to estimate Batillaria and empty shell abundance, shell size, and $Z$. japonica percentage cover at 0 to $150 \mathrm{~m}$ from shore at a 13th, central site (Survey 3). These last data were collected by 4 University of Washington undergraduate classes from July 1999 to October 2000.

For Surveys 1 and 2 we established a transect running perpendicular to shore from the high water mark. At each distance we haphazardly placed three $25 \times$ $25 \mathrm{~cm}$ quadrats, 0.25 to $1 \mathrm{~m}$ apart (Survey 1 ) or one $50 \times$ $50 \mathrm{~cm}$ quadrat (Survey 2) on the mudflat surface at low tide. We counted all shells in each quadrat and measured shell lengths in one per site. Sampling methods for Survey 3 were as for Survey 1, but with 1 to 4 transects at least $10 \mathrm{~m}$ apart and 1 to 3 quadrats per transect at 0, 50, 100, and $150 \mathrm{~m}$ from shore. Batillaria shell lengths were measured in all quadrats. Nassarius and Pagurus spp. were present at this site, but were too rare to analyze their abundance.

In all surveys, snails and hermit crabs were detected by sight and touch from the surface to a sediment depth of $5 \mathrm{~cm}$. We found no additional individuals of these 
species in sediment samples retained on a $250 \mu \mathrm{m}$ mesh sieve, confirming the reliability of this field collection method (O'Connor et al. 2002). Zostera japonica percentage cover was estimated using a 50 point grid on the sampling quadrats. Batillaria shell lengths were measured from apex to aperture to the nearest mm.

Epibiont abundance and distribution. To quantify the use of Batillaria shells as habitat, we surveyed shell epifauna at 3 sites in March 2001. At each site, approximately 100 shells were collected at each distance 0, 50, 100 and $150 \mathrm{~m}$ from shore. Shell occupants (Batillaria, Pagurus spp., or empty) and epibionts were identified and counted.

Batillaria manipulation. To experimentally evaluate Batillaria impacts on Nassarius and Pagurus spp. abundance, Zostera japonica percentage cover, sediment chlorophyll level, and sediment grain size, we manipulated snail densities at 1 survey site with high Batillaria densities (1441 $\left.\pm 353 \mathrm{~m}^{-2}, \mathrm{n}=8\right)$. Twentyseven plots were established in a $9 \times 3$ array parallel to the shore, $100 \mathrm{~m}$ from shore. Plots were haphazardly assigned to 3 treatments: snail removal (cage with all live Batillaria removed, $\mathrm{n}=8$ ), snail enclosure (cage enclosing ambient density Batillaria, $\mathrm{n}=11$ ), and open (ambient snail densities in a marked plot with no cage, $\mathrm{n}=8)$. The initial abundance of Nassarius $\left(16 \pm 23 \mathrm{~m}^{-2}\right)$ and Pagurus spp. $\left(21 \pm 28 \mathrm{~m}^{-2}\right)$, which were able to climb in and out of the cages, was not manipulated. Empty Batillaria shells $\left(1.8 \pm 5.0 \mathrm{~m}^{-2}\right)$ were not manipulated and did not differ significantly in abundance at the end of the experiment.

Cages consisted of circular roofless fences, $30 \mathrm{~cm}$ tall and $56 \mathrm{~cm}$ in diameter, made of $3 \mathrm{~mm}$ galvanized mesh. They were buried $10 \mathrm{~cm}$ into the sediment and anchored with $50 \mathrm{~cm}$ stakes. Plots were established in early April 2000 and stray Batillaria were evicted from the removal cages after 2 and 10 wk. After 18 wk, we counted all snails and hermit crabs and estimated eelgrass abundance, chlorophyll levels, and sediment size in each plot.

Eelgrass percentage cover was photographed and subjectively estimated from $35 \mathrm{~mm}$ slides (following Dethier et al. 1993) without observer knowledge of treatment. For chl $a$, multiple $0.5 \mathrm{~cm}$ deep sediment samples were pooled to a $3 \mathrm{ml}$ volume and stored at $-10^{\circ} \mathrm{C}$. Chlorophyll was determined by fluorometry following a $24 \mathrm{~h}$ extraction at $4{ }^{\circ} \mathrm{C}$ in $80 \%$ methanol and correcting for phaeopigments (following Marker et al. 1980). For particle size analysis, sediment was pooled and homogenized from 3 cores, $3 \mathrm{~cm}$ deep and $1 \mathrm{~cm}$ in diameter. Silt:sand ratios were determined by placing subsamples of 1 to $2 \mathrm{ml}$ in a $2 \mathrm{~m}$ tall glass cylinder filled with water (following Emery 1938). Settled particle volumes were recorded after $4 \mathrm{~min}$ (sand, diameter $>63 \mu \mathrm{m}$ ) and $12 \mathrm{~h}$ (silt, diameter $<63 \mu \mathrm{m}$ ). The remain- ing volume of suspended clay constituted $<1 \%$ of the particles by volume in trial runs.

Data analysis. Count and size data were $\ln (x)$-transformed and proportion data were arcsin-square-roottransformed to improve normality. To test for relationships between the abundance of empty Batillaria shells, Pagurus spp., and Nassarius vs. Batillaria abundance, we used repeated measures regressions (Survey 1). To examine the spatial distribution of Batillaria, we used 1-way ANOVA (Survey 2) and repeated measures ANOVA (Survey 3) for abundance vs. distance from shore. To test for relationships between empty Batillaria shell abundance, Batillaria shell length, and Zostera japonica percentage cover vs. Batillaria abundance and distance from shore, we used ANCOVA (Survey 2) and repeated-measures ANCOVA (Survey 3), after determining that, in all cases, the interaction effect between Batillaria abundance and distance was nonsignificant.

All data from the Batillaria removal experiment were analyzed with 1-way ANOVA by treatment. Significant results were explored with post-hoc pairwise Student's $t$-tests. Shell epibiont distribution was analyzed with 1-way ANOVA and $\mathrm{Chi}^{2}$ tests. Analyses were conducted in JMP Version 3.2.6 for Macintosh (@SAS Institute 1988-1999) using a significance level of $\alpha=$ 0.05 . All mean values in the text are presented $\pm 1 \mathrm{SD}$.

\section{RESULTS}

\section{Spatial distribution surveys}

In Survey 1, empty Batillaria shell and Nassarius abundances increased significantly with live Batillaria abundance (Survey 1, Fig. 1A,B, Table 1). Pagurus spp. abundance tended to increase as well, but this relationship was weak (Survey 1, Fig. 1C, Table 1). The total abundance of Batillaria shells in this survey averaged $833 \pm 1052 \mathrm{~m}^{-2}$, of which live Batillaria constituted $88.7 \%$ (mean abundance $738 \pm 1029 \mathrm{~m}^{-2}$ ) and empty shells constituted $8.8 \%\left(73 \pm 152 \mathrm{~m}^{-2}\right)$. Pagurus spp. (mean abundance $21 \pm 47 \mathrm{~m}^{-2}$ ) occupied the remaining $2.5 \%$ of all Batillaria shells, or $22 \%$ of snail-less shells. Nassarius abundance averaged $21 \pm 28 \mathrm{~m}^{-2}$; all shells were $<1 \mathrm{~cm}$ long and were occupied by live snails. We found no other macrofaunal species in the survey quadrats.

Species distributional patterns varied with distance from shore in some but not all surveys (Tables $2 \& 3$ ). Across all sites, live Batillaria abundance averaged $429 \pm 407 \mathrm{~m}^{-2}$ and did not vary with distance (Survey 2, Table 2). At the single site, however, it decreased significantly with distance from $2293 \pm 576 \mathrm{~m}^{-2}$ at $0 \mathrm{~m}$ to $1483 \pm 572 \mathrm{~m}^{-2}$ at $50 \mathrm{~m}, 959 \pm 314 \mathrm{~m}^{-2}$ at $100 \mathrm{~m}$, and $480 \pm 284 \mathrm{~m}^{-2}$ at $150 \mathrm{~m}$ (Survey 3, Table 3). Empty shell 

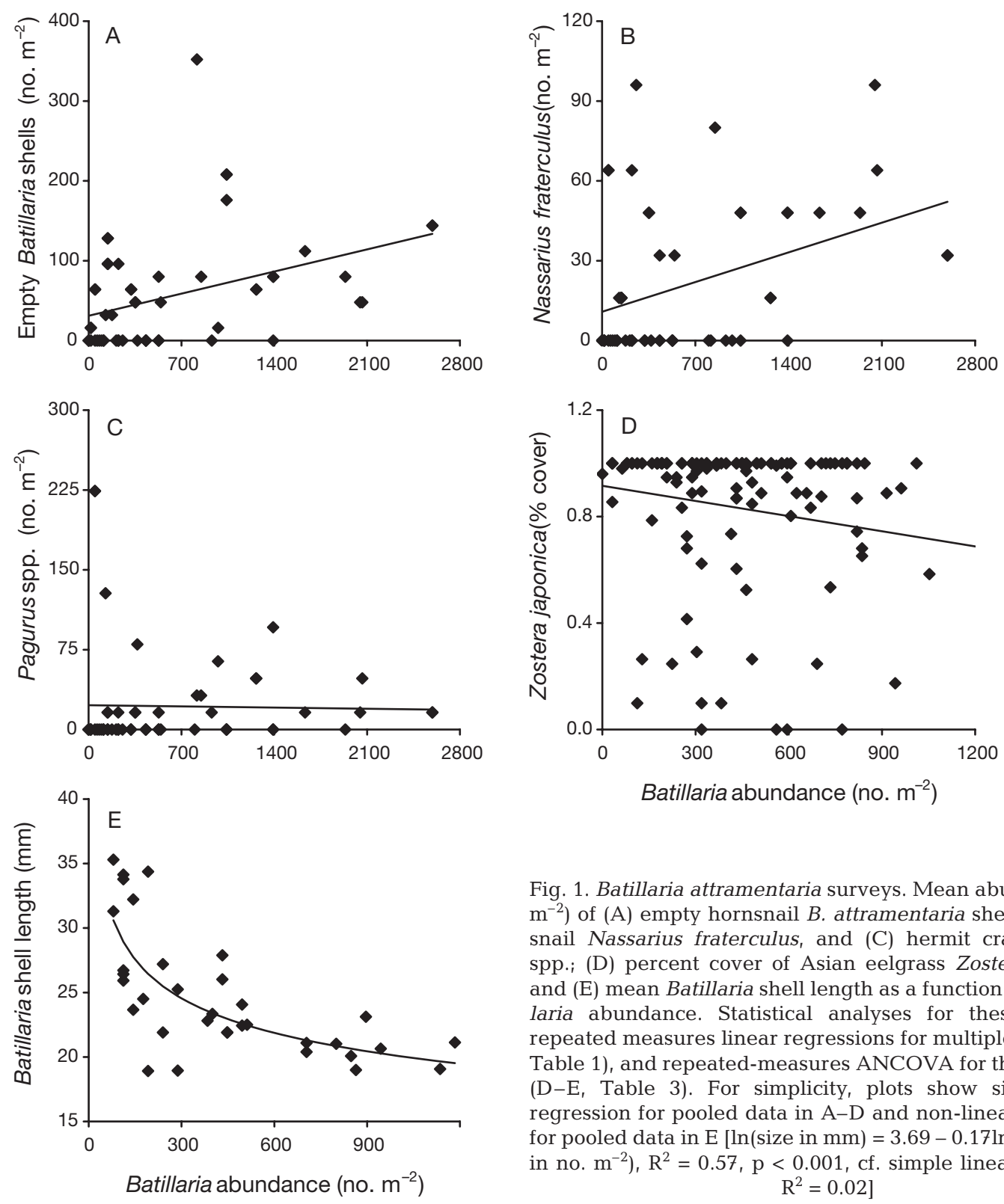

abundance increased significantly with increasing Batillaria abundance, but showed no effect of distance across all sites or at the single site (Tables $2 \& 3$ ).

Zostera japonica percentage cover averaged $27.7 \pm$ 40.6 across all sites, or $47.7 \pm 43.5(n=6)$ excluding the sites with no $Z$. japonica, and did not vary with distance or Batillaria abundance (Table 2). At the single site, Z. japonica percentage cover decreased significantly with increasing distance and tended to decrease with increasing Batillaria abundance (Table 3, Fig. 1D).

Batillaria shell lengths decreased significantly with increasing Batillaria abundance across all sites and at the single site, where it also increased significantly with distance (Tables 2 \& 3, Fig. 1E).

Fig. 1. Batillaria attramentaria surveys. Mean abundance (no. $\mathrm{m}^{-2}$ ) of (A) empty hornsnail B. attramentaria shells, (B) mudsnail Nassarius fraterculus, and (C) hermit crabs Pagurus spp.; (D) percent cover of Asian eelgrass Zostera japonica, and (E) mean Batillaria shell length as a function of live Batillaria abundance. Statistical analyses for these data are repeated measures linear regressions for multiple sites (A-C, Table 1), and repeated-measures ANCOVA for the single site (D-E, Table 3). For simplicity, plots show simple linear regression for pooled data in $\mathrm{A}-\mathrm{D}$ and non-linear regression for pooled data in $\mathrm{E}[\ln ($ size in $\mathrm{mm})=3.69-0.17 \ln$ (abundance in no. $\mathrm{m}^{-2}$ ), $\mathrm{R}^{2}=0.57, \mathrm{p}<0.001$, cf. simple linear regression $\left.\mathrm{R}^{2}=0.02\right]$

\section{Epibiont abundance and distribution}

Given mean Batillaria shell densities of approximately $400 \mathrm{~m}^{-2}$, and an average shell area of $3.06 \mathrm{~cm}^{2}$ (based on half the surface area of a cone $24 \mathrm{~mm}$ tall and $8 \mathrm{~mm}$ across at the base), we estimate that Batillaria provides $600 \mathrm{~cm}^{2}$ of hard substratum per $\mathrm{m}^{2}$ of mudflat. Not all this substratum was visibly exploited: of 1205 Batillaria shells, only 72 (6\%) carried 1 or more epibionts (Table 4).

Shells occupied by Pagurus spp. were colonized by epibionts significantly more frequently than were live Batillaria or empty shells (Table $4 ; 1$-way ANOVA $F=$ 5.95, df $=2, \mathrm{p}=0.007$ ). Epibionts consisted almost 
Table 1. Repeated-measures regressions for the abundance of empty Batillaria attramentaria shells, hermit crabs Pagurus spp., and the mudsnail Nassarius fraterculus vs. abundance of live Batillaria $100 \mathrm{~m}$ from shore at 13 sites over 5 sampling dates (4 dates for Pagurus spp. and Nassarius) (Survey 1). All relationships with Batillaria abundance were positive (See Fig. 1). SS: sum of squares; df: degrees of freedom; F: F-ratio; p: probability ( $\mathrm{p}<0.05$ in bold, $\mathrm{p}<0.1$ in italics); $\mathrm{R}^{2}$ : proportion of total variance explained by model

\begin{tabular}{|c|c|c|c|c|c|c|}
\hline Response & Factor & SS & df & $F$ & $\mathrm{p}$ & $\mathrm{R}^{2}$ \\
\hline Empty Batillaria shells & $\begin{array}{l}\text { Batillaria (+) } \\
\text { Date }\end{array}$ & $\begin{array}{l}32.60 \\
14.82\end{array}$ & $\begin{array}{l}1 \\
3\end{array}$ & $\begin{array}{l}8.32 \\
1.26\end{array}$ & $\begin{array}{l}\mathbf{0 . 0 0 6} \\
0.301\end{array}$ & 0.222 \\
\hline Pagurus spp. & $\begin{array}{l}\text { Batillaria (+) } \\
\text { Date }\end{array}$ & $\begin{array}{r}10.35 \\
5.73\end{array}$ & $\begin{array}{l}1 \\
4\end{array}$ & $\begin{array}{l}3.01 \\
0.42\end{array}$ & $\begin{array}{l}0.089 \\
0.796\end{array}$ & 0.083 \\
\hline Nassarius fraterculus & $\begin{array}{l}\text { Batillaria (+) } \\
\text { Date }\end{array}$ & $\begin{array}{l}16.82 \\
16.82\end{array}$ & $\begin{array}{l}1 \\
4\end{array}$ & $\begin{array}{l}5.06 \\
0.61\end{array}$ & $\begin{array}{l}\mathbf{0 . 0 3 0} \\
0.615\end{array}$ & 0.145 \\
\hline
\end{tabular}

Table 2. One-way ANOVA for the abundance of Batillaria attramentaria abundance vs. distance from shore, and ANCOVA for empty shell abundance, shell length, and eelgrass Zostera japonica percent cover vs. Batillaria abundance and distance from shore, in bay-wide surveys (Survey 2: 12 sites; 50, 100, and $150 \mathrm{~m}$ from shore; 1 sampling date). Significant positive (+) and negative (-) relationships indicated for Batillaria (continuous) and distance (categorical) factors. Abbreviations as per Table 1

\begin{tabular}{|lllrrrr}
\hline Response & Factor & SS & df & $F$ & $\mathrm{p}$ & $\mathrm{R}^{2}$ \\
\hline Live Batillaria & Distance & 11.99 & 2 & 2.11 & 0.126 & 0.039 \\
Empty Batillaria & Batillaria (+) & 46.60 & 1 & 15.20 & $<\mathbf{0 . 0 0 1}$ & 0.137 \\
shell abundance & Distance & 8.37 & 2 & 1.36 & 0.260 & 0.742 \\
Zostera japonica & Batillaria & 0.02 & 1 & 0.11 & 0.030 \\
(all sites) & Distance & 0.14 & 2 & 0.42 & 0.659 \\
Z. japonica & Batillaria & 0.07 & 1 & 0.33 & 0.573 & 0.060 \\
(sites where present) & Distance & 0.16 & 2 & 0.40 & 0.673 & \\
Live Batillaria & Batillaria (-) & 0.54 & 1 & 34.15 & $<\mathbf{0 . 0 0 1}$ & 0.583 \\
shell length & Distance & 0.02 & 2 & 0.55 & 0.554 \\
\hline
\end{tabular}

Table 3. Repeated-measures ANOVA for the abundance of Batillaria attramentaria abundance vs. distance from shore, and RMANCOVA for empty shell abundance, shell length, and eelgrass Zostera japonica percent cover vs. Batillaria abundance and distance from shore, in repeated surveys at a single site (Survey 3: 1 site; 0, 50, 100, and $150 \mathrm{~m}$ from shore, 4 sampling dates). Significant positive $(+)$ and negative $(-)$ relationships indicated for Batillaria (continuous) and distance (categorical) factors. Abbreviations as per Table 1

\begin{tabular}{|c|c|c|c|c|c|c|}
\hline Response & Factor & SS & df & $F$ & $\mathrm{p}$ & $\mathrm{R}^{2}$ \\
\hline Live Batillaria & $\begin{array}{l}\text { Distance (-) } \\
\text { Date }\end{array}$ & $\begin{array}{l}4.94 \\
3.49\end{array}$ & $\begin{array}{l}3 \\
3\end{array}$ & $\begin{array}{l}2.95 \\
2.09\end{array}$ & $\begin{array}{l}\mathbf{0 . 0 3 6} \\
0.106\end{array}$ & 0.109 \\
\hline $\begin{array}{l}\text { Empty Batillaria } \\
\text { shells }\end{array}$ & $\begin{array}{l}\text { Batillaria (+) } \\
\text { Distance } \\
\text { Date }\end{array}$ & $\begin{array}{r}8.06 \\
2.44 \\
64.63\end{array}$ & $\begin{array}{l}1 \\
3 \\
3\end{array}$ & $\begin{array}{r}5.70 \\
0.80 \\
15.23\end{array}$ & $\begin{array}{r}\mathbf{0 . 0 1 9} \\
0.632 \\
<\mathbf{0 . 0 0 1}\end{array}$ & 0.328 \\
\hline $\begin{array}{l}\text { Zostera japonica } \\
\text { percent cover }\end{array}$ & $\begin{array}{l}\text { Batillaria (-) } \\
\text { Distance (-) } \\
\text { Date }\end{array}$ & $\begin{array}{l}0.44 \\
3.33 \\
3.34\end{array}$ & $\begin{array}{l}1 \\
3 \\
2\end{array}$ & $\begin{array}{r}3.57 \\
8.98 \\
13.50\end{array}$ & $\begin{array}{r}0.062 \\
<\mathbf{0 . 0 0 1} \\
0.126\end{array}$ & 0.364 \\
\hline $\begin{array}{l}\text { Live Batillaria } \\
\text { shell length }\end{array}$ & $\begin{array}{l}\text { Batillaria (-) } \\
\text { Distance (+) } \\
\text { Date }\end{array}$ & $\begin{array}{l}0.06 \\
2.49\end{array}$ & $\begin{array}{c}1 \\
3 \\
0.11\end{array}$ & $\begin{array}{r}4.22 \\
55.18 \\
3\end{array}$ & $\begin{aligned} \mathbf{0 . 0 4 2} \\
<\mathbf{0 . 0 0 1} \\
2.39\end{aligned}$ & $\begin{array}{l}0.632 \\
0.072\end{array}$ \\
\hline
\end{tabular}

exclusively of Diadumene and Crepidula, which were differently distributed (Table 4). Crepidula was more abundant on Pagurus spp. and empty shells than on Batillaria, whereas Diadumene was more abundant on Batillaria than on empty or Pagurus spp. shells. These host-epifaunal associations were distributed significantly differently from uniform in contingency table analyses ( 2 epibionts $\times 3$ shell types) for both the number of fouled shells $\left(\chi^{2}=13.15, \mathrm{df}=2, \mathrm{p}=0.001\right)$ and the number of epibiont individuals $\left(\chi^{2}=64.8, \mathrm{df}=\right.$ $2, \mathrm{p}<0.001)$. Only 1 shell was fouled by both Crepidula and Diadumene, compared to 40 shells colonized by Crepidula alone and 30 by Diadumene alone. 
Table 4. Frequency and distribution of epifaunal species on Batillaria attramentaria shells. Frequency of fouling given for shells occupied by live snails, by hermit crabs Pagurus spp., or empty (SD: 1 standard deviation; N: number of samples of 100 to 120 shells each). Distribution of epibionts given for introduced Atlantic slipper shells Crepidula convexa and introduced Asian anemones Diadumene lineata (number of individuals followed by number of shells in parentheses). Shells sampled at 12 locations in Padilla Bay, Washington, 2000

\begin{tabular}{|lccc|}
\hline Epifauna & Batillaria & $\begin{array}{c}\text { Pagurus } \\
\text { spp. }\end{array}$ & Empty \\
\hline Frequency & & & \\
$\quad$ Total shells & 1062 & 61 & 82 \\
$\quad$ Mean proportion fouled & 0.037 & 0.470 & 0.131 \\
SD (N) & $0.059(12)$ & $0.454(9)$ & $0.205(12)$ \\
Distribution & & & \\
No. Crepidula (shells) & $9(6)$ & $26(12)$ & $22(14)$ \\
No. Diadumene (shells) & $33(7)$ & $0(0)$ & $2(2)$ \\
& & & \\
\hline
\end{tabular}
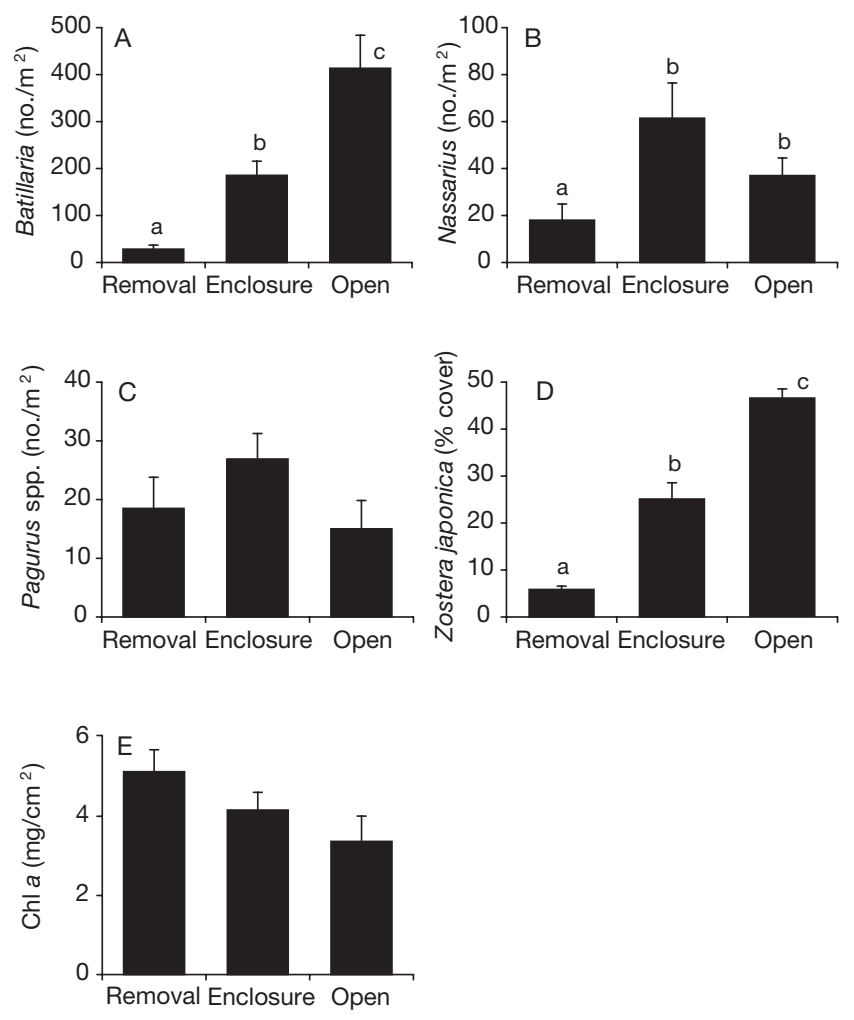

Fig. 2. Batillaria attramentaria removal experiment. Mean (A) hornsnail B. attramentaria abundance, (B) mudsnail Nassarius fraterculus abundance, (C) hermit crabs Pagurus spp. abundance, (D) eelgrass Zostera japonica percentage cover, and (E) sediment chlorophyll levels at the end of the experiment. When Batillaria densities were reduced, Nassarius abundance and Zostera cover were significantly increased, Pagurus spp. showed no effect, and chlorophyll level tended to decrease. Error bars show $1 \mathrm{SE}$; letters above bars indicate significantly different groups in post-hoc analysis
Additional shell and epibiont species were rare. Other epibionts consisted of mussels Mytilus sp., unidentified eggs, and brown macroalgae on 4 live Batillaria shells, and spirorbid polychaetes on 4 Pagurus spp. shells. We also found 4 Nassarius shells with Crepidula, Diadumene, and Pagurus spp., and 1 LaCuna sp. shell occupied by a Pagurus sp.

\section{Batillaria manipulation}

Batillaria density treatments differed significantly from each other at the end of the experiment (Fig. 2A; ANOVA $F=43.4, \mathrm{df}=2, \mathrm{p}<0.0001)$. The higher abundance in open plots than in enclosures indicates a net snail emigration from the cages. Comparison of removals to enclosures therefore illustrates the effect of Batillaria, and comparison of enclosures to open plots illustrates the combined Batillaria and cage effect. Both Nassarius and Zostera japonica increased with increasing Batillaria abundance. Nassarius abundance was significantly greater in Batillaria enclosures and open plots than in removals (Fig. 2B; ANOVA $F=4.92$, df $=2$, $\mathrm{p}=0.016)$. $Z$. japonica percentage cover was significantly higher in open plots than in enclosures, and in enclosures than in removals (Fig. 2C; ANOVA $F=57.9$, $\mathrm{df}=2, \mathrm{p}<0.0001$ ). Pagurus spp. abundance did not differ significantly among treatments (Fig. 2D; ANOVA $F=1.21, \mathrm{df}=2, \mathrm{p}=0.32$ ). Sediment $\mathrm{chl}$ a concentration tended to decrease from removal to enclosure to open treatments, but this was not statistically significant (Fig. 2E; ANOVA $F=2.53, \mathrm{df}=2, \mathrm{p}=0.101$ ). Sand: silt ratios did not differ significantly among open (0.41 \pm $0.03, \mathrm{n}=7)$, enclosure $(0.40 \pm 0.02, \mathrm{n}=11)$, or removal treatments $(0.41 \pm 0.02, \mathrm{n}=8)$.

\section{DISCUSSION}

The intertidal mudflat assemblage of Padilla Bay is dominated by 7 conspicuous species. The most abundant of these is the introduced hornsnail Batillaria, which reaches densities averaging $429 \mathrm{~m}^{-2}$ and exceeding $1400 \mathrm{~m}^{-2}$. The significant negative relationship we report between Batillaria abundance and size may indicate some density-dependent limitation in this population. Notably, these observed high densities are attained despite a nearly $90 \%$ prevalence of infection by the castrating trematode parasite Cercaria batillariae (J. Byers, University of New Hampshire, and M. Torchin, National Center for Ecological Analysis and Synthesis, pers. comm. to M. J. Wonham).

Batillaria significantly affects the abundances of 2 epibionts, 3 other grazers, and 1 eelgrass species. For epibionts, Batillaria shells provide on average $600 \mathrm{~cm}$ 
$\mathrm{m}^{-2}$ of hard substratum in a mudflat system. The 2 dominant epibionts, the Asian anemone Diadumene and the Atlantic slippershell Crepidula, are rarely, if ever, found free-living on the mudflat surface. In the absence of Batillaria, neither would find much available habitat, as there are no other native snail shells present, and shells of the other introduced snail, Nassarius, are smaller and much less abundant. The relative abundance of unfouled Batillaria shells suggests, however, that this resource is not fully exploited in Padilla Bay.

Although we found no significant effects of Batillaria on sediment chlorophyll levels, this species alters diatom community structure and sediment organic carbon in other mudflat systems (Byers 2000, Kamimura \& Tsuchiya 2004). If Batillaria reduced grazer resources, other grazers might be expected to segregate spatially from Batillaria as a result of competition. Alternatively, they could aggregate with Batillaria if they were attracted to the same diatom resources, or if selective grazing by Batillaria (Whitlatch \& Obrebski 1980, Byers 2000) enhanced the abundance of the other grazers' preferred diatoms. In addition, hermit crabs might be expected to aggregate to empty shells, the abundance of which is positively correlated with live Batillaria abundance. We found no significant evidence of positive or negative association in abundance between Pagurus spp. and Batillaria. We therefore suggest that the primary influence of Batillaria on the Pagurus spp. population in this system is simply habitat provision. The other grazing snail, Nassarius, was positively associated with Batillaria in both surveys and experimental studies. We suggest that selective grazing by Batillaria may indirectly enhance the preferred diatom resources of Nassarius, leading to aggregation of the 2 species.

Shells occupied by Pagurus spp. were more exploited by Crepidula and less by Diadumene than shells occupied by live Batillaria, indicating indirect as well as direct effects of Batillaria on the 2 epibionts. This association among snail, crab, and epibiont species from different ocean basins is strikingly similar to associations of analogous native species in both the Atlantic and Pacific (e.g. Morton 1980, Karlson \& Cariolou 1982, McDermott 2001). Thus, Batillaria appears to affect native grazers and introduced epibionts through habitat provision, and the introduced grazer through indirect trophic effects.

Batillaria enhanced the percentage cover of eelgrass Zostera japonica in the manipulative experiment. Across sites there was no significant relationship between these species, although at the single site there was a negative trend in their association. Differences between the bay-wide and single-site results may partially reflect the absence of samples at $0 \mathrm{~m}$ from shore in Survey 2, which is where the smallest and most abundant Batillaria were found in Survey 3. In addition, minor site differences in topography, wave energy and sediment composition mean that distance from shore is not a perfect proxy for intertidal height, and may have contributed to variation among sites. In similar softsediment habitats, bioturbation and pseudofecal deposition affect oxygen and nutrient levels in the sediment and water (e.g. Reise 2002, Kamimura \& Tsuchiya 2004). These factors are known to affect eelgrass growth (e.g. Peterson \& Heck 2001). We suggest that by modifying oxygen and nutrient levels, Batillaria indirectly facilitates $Z$. japonica, and that these mechanisms are more readily observed in enclosed cages than in the more diffuse system of the open bay. These hypothesized mechanisms of facilitation for Pagurus spp., Nassarius, and Z. japonica remain to be investigated in future work.

We provisionally define Batillaria's impacts on all 6 species as positive. For the 4 other non-native species, this illustrates multiple positive effects of a marine invader. We note, however, that a complete determination of Batillaria's impacts and an assessment of the associated process of invasional meltdown (Simberloff \& Von Holle 1999) requires an understanding of Batillaria's net effects on these other invaders, and the role of each invader's local population as a sink or source in the larger region. In addition, since exact arrival dates of each invader are unknown, the importance of positive interactions in their early establishment vs later spread cannot be determined. Nonetheless, Batillaria appears to increase the invasibility of this mudflat, as well as the potential population size, and therefore the chance of persistence and the total impacts, of 6 other species. The mechanism of enhancement for 5 of these species is habitat provision, or ecosystem engineering (Crooks 2002), in a manner consistent with the conceptual model of increased resource availability enhancing community invasibility (Sher \& Hyatt 1999, Davis et al. 2000). The mechanism for the 6th species (Nassarius) may be indirect trophic interactions. This suite of Batillaria impacts is a central component of the combined invasion of over 25 species to the NE Pacific via commercial shipments of both Pacific and Atlantic oysters (Carlton 1979, 1987, 1992, Wonham \& Carlton 2005). To fully appreciate the consequences of this larger invader assemblage, the direct and indirect impacts of the majority of these species remain to be assessed.

Acknowledgements. We are grateful for the taxonomic expertise of J. Carlton, R. Collin, and A. Kohn (molluscs), C. Mills (anemones), and B. Pernet (annelids), and for laboratory space at Brown University provided by S. Hamburg. J. Byers, J. Pearse, E. Von Holle, and anonymous reviewers provided valuable comments on earlier versions. This work was supported by a Padilla Bay National Estuarine Research Reserve 'Research Assistantship in Estuarine Science and Coastal Zone Management,' managed by the Washington State Department of Ecology and funded by the Padilla Bay Foundation and Tesoro Northwest Oil Company. 


\section{LITERATURE CITED}

Alpine AE, Cloern JE (1992) Trophic interactions and direct physical effects control phytoplankton biomass and production in an estuary. Limnol Oceanogr 37(5):946-955

Bruno JF, Stachowicz J, Bertness M (2003) Inclusion of facilitation into ecological theory. Trends Ecol Evol 18:119-125

Byers JE (2000) Competition between two estuarine snails: implications for invasions of exotic species. Ecology 81: $1225-1239$

Carlton JT (1979) History, biogeography, and ecology of the introduced marine and estuarine invertebrates of the Pacific coast of North America. PhD thesis, University of California, Davis, CA

Carlton JT (1987) Patterns of transoceanic marine biological invasions in the Pacific Ocean. Bull Mar Sci 41:452-465

Carlton JT (1992) Introduced marine and estuarine mollusks of North America: an end-of-the-20th-century perspective. J Shellfish Res 11:489-505

Castilla JC, Lagos NA, Cerda M (2004) Marine ecosystem engineering by the alien ascidian Pyura praeputialis on a mid-intertidal rocky shore: species richness, distribution and spatial turnover. Mar Ecol Prog Ser 268:119-130

Crooks J (2002) Characterizing ecosystem-level consequences of biological invasions: the role of ecosystem engineers. Oikos 97:153-166

D'Antonio CM, Vitousek P (1992) Biological invasions by exotic grasses, the grass/fire cycle, and global change. Annu Rev Ecol Syst 23:63-87

Davis M, Grime J, Thompson K (2000) Fluctuating resources in plant communities: a general theory of invasibility. $\mathrm{J}$ Ecol 88:528-534

Dethier MN, Graham ES, Cohen S, Tear LM (1993) Visual versus random-point percent cover estimations: 'objective' is not always better. Mar Ecol Prog Ser 96:93-100

Emery KO (1938) Rapid method of mechanical analysis of sands. J Sedimentol Petrol 8:105-111

Gollasch S, Riemann-Zürneck K (1996) Transoceanic dispersal of benthic macrofauna: Haliplanella luciae (Verrill, 1898) (Anthozoa, Actiniaria) found on a ship's hull in a shipyard dock in Hamburg Harbour, Germany. Helgol Meeresunters 50:253-258

Grosholz T (2002) Ecological and evolutionary consequences of coastal invasions. Trends Ecol Evol 17(1):22-27

Jeffrey R (1976) A preliminary inventory of the biota of Padilla Bay. Washington State Dept Game Padilla Bay National Estuarine Research Reserve Reprint Series 1 (1990), Mount Vernon, WA

Kamimura S, Tsuchiya M (2004) The effect of feeding behavior of the gastropods Batillaria zonalis and Cerithideopsilla cingulata on their ambient environment. Mar Biol 144: 705-712

Karlson RH, Cariolou MA (1982) Hermit crab shell colonization by Crepidula convexa Say. J Exp Mar Biol Ecol 65:1-10

Kitchell JF, Schindler DE, Ogutu-Ohwayo R, Reinthal PN (1997) The Nile perch in Lake Victoria: interactions between predation and fisheries. Ecol Appl 7:653-664

Lambert CC, Lambert G (2003) Persistence and differential distribution of nonindigenous ascidians in harbors of the Southern California Bight. Mar Ecol Prog Ser 259:145-161

Levin PS, Coyer JA, Petrik R, Good TP (2002) Communitywide effects of non-indigenous species on temperate rocky reefs. Ecology 83:3182-3193

Marker AFH, Crowther CA, Gunn RJM (1980) Methanol and acetone as solvents for estimating chlorophyll $a$ and phaeopigments by spectrophotometry. Ergeb Limnol 14: 52-69
McDermott JJ (2001) Symbionts of the hermit crab Pagurus spp. longicarpus Say, 1817 (Decapoda: Anomura): new observations from New Jersey waters and a review of all known relationships. Proc Biol Soc Wash 114:624-639

Morton B (1980) Selective site segregation in Patelloida (Chiazacmea) pygmaea (Dunker) and $P$. (C.) lampanicola Habe (Gastropoda: Patellacea) on a Hong Kong shore. J Exp Mar Biol Ecol 47:149-171

Mouritsen KN (2004) Intertidal facilitation and indirect effects: causes and consequences of crawling in the New Zealand cockle. Mar Ecol Prog Ser 271:207-220

O'Connor M, Wonham MJ, Harley C (2002) Quantifying the impacts of an invader: the Asian mud snail Batillaria attramentaria on the mud flats of Padilla Bay, Washington. Washington State Department of Ecology Publication No 02-06-016. Padilla Bay National Estuarine Research Reserve Technical Report No 25, Mount Vernon, WA

Parker IM, Simberloff D, Lonsdale WM, Goodell K and 7 others (1999) Impact: assessing the ecological effects of invaders. Biol Invasions 1:3-19

Penttila D (1971) Introduced marine mollusks of Washington and Oregon: a critical essay in partial fulfillment of the requirements for a Master of Science Degree in Biology. Oregon Institute of Marine Biology Library, Charleston, OR

Peterson BJ, Heck KL Jr (2001) Positive interactions between suspension-feeding bivalves and seagrass - a facultative mutualism. Mar Ecol Prog Ser 213:143-155

Reise K (2002) Sediment mediated species interactions in coastal waters. J Sea Res 48:127-141

Ricciardi A (2001) Facilitative interactions among aquatic invaders: is an 'invasional meltdown' occurring in the Great Lakes? Can J Fish Aquat Sci 58:2513-2525

Ricciardi A (2003) Predicting the impacts of an introduced species from its invasion history: an empirical approach applied to zebra mussel invasions. Freshw Biol 48: 972-981

Richardson DM, Allsopp N, D'Antonio CM, Milton SH, Rejmánek M (2000) Plant invasions - the role of mutualisms. Biol Rev Camb Phil Soc 75:65-93

Sher AA, Hyatt LA (1999) The disturbed resource-flux invasion matrix: a new framework for patterns of plant invasion. Biol Invasions 1:107-114

Simberloff D, Von Holle B (1999) Positive interactions of nonindigenous species: invasional meltdown? Biol Invasions $1: 21-32$

Stachowicz JJ (2001) Mutualism, facilitation, and the structure of ecological communities. BioScience 51:235-246

Sylvester RO, Clogston FL (1958) A study of the preoperational marine environment in the vicinity of the Texas Company Refinery Puget Sound Works, Anacortes, Washington for the Texas Company

Wasson K, Zabin CJ, Bedinger L, Diaz MC, Pearse JS (2001) Biological invasions of estuaries without international shipping: the importance of intraregional transport. Biol Conserv 100:143-153

Whitlatch RB, Obrebski S (1980) Feeding selectivity and coexistence in two deposit-feeding gastropods. Mar Biol 58:219-225

Wonham MJ (2003) Ecological gambling: expendable extinctions vs. acceptable invasions. In: Kareiva P, Levin S (eds) The importance of species. Princeton University Press, Princeton, NJ, p 179-205

Wonham MJ, Carlton JT (2005) Trends in marine biological invasions at local and regional scales: the Northeast Pacific Ocean as a model system. Biol Invasions in press

Submitted: March 3, 2004; Accepted: October 7, 2004

Proofs received from author(s): February 21, 2005 